DOI: $10.17516 / 1997-1370-0607$

УДК 332.14

\title{
Igarka as a Frontier: Lessons from the Pioneer of the Northern Sea Route
}

\author{
Nadezhda Yu. Zamiatina* \\ Lomonosov Moscow State University \\ Moscow, Russian Federation \\ Laboratory of Historical Geography and Regionalism \\ Tyumen State University \\ Tyumen, Russian Federation
}

Received 05.03.2020, received in revised form 30.04.2020, accepted 12.05.2020

\begin{abstract}
The article considers the development trajectory of Igarka, a pioneer export port of the Northern Sea Route. The focus is made on analyzing the possibilities of preserving the town after the collapse of the town-forming enterprises. The main conceptual framework of the analysis is the Jack London's hypothesis introduced by Alaskan economist Lee Husky (about potential of frontier cities for further development in the post-boom period). The findings are that the reason for the current economic and social crises in Igarka is not only the change in the conditions of timber export and navigation along the Northern Sea Route in the 1990s, but also the reduced economic functions of the town, as well as the decrease in the diversity of the urban environment as a whole, after paradoxically record production indicators in the last Soviet decades.
\end{abstract}

Keywords: resource development, Northern Sea Route, export, transport, frontier, cyclical economic development, boom and bust, dependence on course, Jack London's effect.

The work was carried out within the framework of the state task of the Ministry of Education and Science of the Russian Federation No. 33.2257.2017/PCh "Russian harbours of Trans-Arctic Railway: spaces and communities of the Arctic coast of Russia on the eve of a new era of the Northern Sea Route development".

Research area: sociological sciences.

Citation: Zamiatina, N.Yu. (2020). Igarka as a frontier: lessons from the pioneer of the Northern Sea Route. J. Sib. Fed. Univ. Humanit. Soc. Sci., 13(5), 783-799. DOI: 10.17516/1997-1370-0607.

\footnotetext{
(C) Siberian Federal University. All rights reserved

* Corresponding author E-mail address: nadezam@yandex.ru ORCID: 0000-0002-4941-9027
} 
Igarka is a port on the river Yenisei which has been specializing in the transporting the exported Siberian timber to the sea ships moving along the Northern Sea Route and further to the foreign ports. Being at the $2^{\text {nd }}$ place in the USSR after Arkhangelsk, Igarka was posited as one of their "currency producer" of the country.

Founded in 1929, Igarka was one of the first Soviet towns in the Arctic, and an iconic symbol of the success of the Soviet power in the North exploration. "Look at the map of our North. According to Stalin's decree, lights of new towns and district centres shone across the Arctic. Whereas 12 years ago Trans-Polar Igarka had only 49 people, now it has 20 thousand inhabitants," I.D. Papanin reported to the XVIII Congress of the Party in 1939 (XVIII s'ezd Vsesoiuznoi..., 1939: 332).

It was with the beginning of timber shipment through Igarka that systematic, "flow" use of the western section of the Northern Sea Route (hereinafter referred to as NSR) as a commercial mainline began. One should bear in mind that by the time Igarka was founded, many attempts had already been made to enter the foreign market from the Yenisei: there had been expeditions of the merchant Mikhail Sidorov, the voyages of captain Viggins and captain Schwanenberg; trade operations of the Norwegian explorer Jonas Lid, the Kara Sea operations of the Kolchak's time and the first years of Soviet power. But it was Igarka's port where these "flow", regular exports started, which made it possible to overcome the economic barrier of high insurance payments for merchant shipping through the NSR: "The increase in tonnage of vessels entering the Yenisei... testifies to the higher degree of studying the conditions of passing, and hence to the reduction of danger of these voyages. There was a pattern of annually decreasing amount of insurance to be paid by ships leaving for Igarka," the town reported in 1935 (Ostroumova et al., 1935: 7).

Being the "showcase" of the Soviet Transpolar region, the "heroine" of many reports and books, Igarka went through one of the most catastrophic scenarios of transformation in the post-Soviet era; it lost its town-forming enter- prise, almost three-quarters of the population and the status of a town of regional subordination. And the deeper one penetrates into Igarka's fate, the more one wonders how inevitable this tragedy was.

First of all, the most characteristic point is the contrast between the efforts of the first builders to create a town with a permanent population, a diversified economy, self-sufficiency in food supply, a town which was to become a cultural and information centre of the vast area of the Transpolar region, and the final of this classic mono-profile settlement, fully dependent on the town-forming enterprise. More than that, even the famous by itself Igarsky Pedagogical College of the Indigenous People of the North was closed after the cessation of timber transshipment, although there had to be no technological or financial connection between the college and the town-forming enterprise.

This article is an attempt to rethink the economic history of Igarka in terms of the concept of the frontier, and in particular Jack London's effect proposed by the Alaskan economist Lee Husky (Huskey, 2017). The main material used in this work is interviews and personal observations made during the trips to Igarka in 2013 (3 expert and 1 in-depth interview) and 2018 (18 expert and 15 in-depth interviews taken during the joint expedition with M. Agapov and F. Korandey, my colleagues from Tyumen State University). Obviously, this material allows researchers to estimate mainly the peculiarities of the last stages of Igarka's development (the memories of the majority of informants did not go earlier than the 1970s, though in some cases there were earlier ones), and also (this is perhaps the most interesting issue) the findings may lead to conclusions about the possibility of other options for Igarka's exit from the frontier cycle. Earlier stages of town development are analyzed according to earlier published sources.

\section{Rises and falls of frontier towns: concept of escaping the resource trap}

The concept of the frontier as a "meeting point between savagery and civilization" (Turner, 2009: 13) was introduced into science 
by the American historian F.J. Turner in his seminal essay "The Significance of the Frontier in American History" published in 1893 (Turner, 1893); Turner's concept was later polished in a book with a similar title (Turner, 2009: 13). He paid much attention to the fact that the frontier is not a line, but rather a border zone, a frontier zone, and this zone is mobile: as the territory becomes developed the frontier is extended to new lands. That is how the frontier zone has "swept" practically all over the United States from the east to the Great Plains, and, according to Turner, the frontier zone had "closed" by the time his historical work was written.

In the Turner's concept, the closure of the frontier implied the transition of the territory to a developed state. Nevertheless, later in the works on the frontier subject there was often raised the issue of boom and bust cycles (Assche Van et al., 2016): the boom of economic activity of the frontier is usually caused, as a rule, by the discovery of a new resource or removing the barrier to its development, and after the boom there logically comes the phase of resource depletion and the corresponding decline in economic activity. The U.S. frontier was mainly associated with the development of new agricultural land, hence the phase of depletion and decline was not as pronounced ${ }^{1}$ as in the case of the mountain frontier (the development of mineral deposits, so called gold and similar fever). The history of the mountain frontier knows a lot of examples of towns being abandoned as soon as the deposit is depleted (ghost towns in the areas of former resource extraction - Kennecott in Alaska with its copper or Forty Mile, Yukon, known for its gold).

In connection with the "diverge point" of the trajectories of development for the territory when its key resource is depleted, the aforementioned work of Anchorage economist Lee Husky is of great interest (Huskey, 2017; see also: Goldsmith, Berman and Huskey, 1987; Huskey, 1987). Husky shows how during a frontier boom there can be created a critical amount of diversified local enterprises in re-

\footnotetext{
Although dust storms that smote the lands of the Great Plains inhabited by the colonists-homesteaders in the 1930s were relatively recent, they can also be considered as a stage of recession for the agricultural frontier.
}

mote areas, enabling the territory's economic development to start with meeting domestic demand; these measures may help to prolong the life of the frontier region after a decline in the export industry. Jack London's hypothesis, the author writes, can be summed up as follows: "Resource exploitation causes such growth and development of related industries that they will be able to exist after the come-down of the resource boom, which in turn stimulates new economic activity." Jack London's hypothesis describes a chance for a more optimistic "postboom" life of frontier towns. Structural changes that occur during the resource booms may change the economic environment in ways that promote future opportunities. Local policymakers may wish to pay attention not simply to resource development but also to the part of the economy that is left behind after the boom" (Huskey, 2017: 344).

Today the specialists wonder why the idea of possible closure of areas of new development was not clearly covered in the first decades of the development of the Soviet North, although the agenda was the very resource development, and American examples of ghost towns at the turn of $19-20^{\text {th }}$ centuries should have been still on everyone's lips.

The study of the 1930s materials brings us closer to the answer to this question: in addition to the narrow task of providing resources for the country's economy, there was an objective of transformation of the North itself. In that logic, the Soviet North simply could not become a zone of shift settlements (although in reality it was to some extent such a zone: with a lot of reservations, GULAG camps can be considered a Stalinist variant of shift-labour development concerning resources of poorly populated territories). In official ideology, the Soviet North was invariably presented as a result of the transformation of the backward and wild North of Tsarist times. This opposition was perfectly voiced in 1934 by S.M. Kirov, who was later quoted many times: "What yesterday seemed completely oblivious, where, as they used to say, 'the sun don't shine', where in Tsarist times people were exiled, now there is a new, rapidly growing industrial centre of the Arctic Circle; it was created by the will of the Bolsheviks in 
the treasury of natural resources (apatite, iron, molybdenum, mica, thorium, titanium, etc.), in the half-tundra, where no man had gone before (17 ${ }^{\text {th }}$ Congress of the All-Union Communist Party (b)). The cliché opposition between the Bolshevik progress (expressed in the involvement of more and more new previously "sleeping" resources in the economic turnover) and the incessant savagery of the Tsarist times, was cited for decades: back in 1960 S.V. Slavin, the chief theorist of the Soviet North exploration, began his book with a passage that "by the time of the Great October Socialist Revolution, the natural resources of the North had been almost not developed and also had not been studied enough..." (Slavin, 1961: 4).

The continuous growth and improvement of socialist production, postulated as the basic economic law of socialism, implied, in particular, the constant need for new resources; the state of constant competition with the hostile capitalist world reinforced this need greatly. The development of the North was seen as an answer to this need (this practice, perhaps, can be extrapolated to all the years of Soviet power). Let us continue reading from Slavin: "the continuous growth of production, caused by the basic economic law of socialism, necessitates not only wider use of the raw materials and fuels of the old, long inhabited and industrially developed areas of the country, but also the development of new areas with large, virgin natural resources... Further growth of the national economy and the solution of the main economic task of the USSR, i.e. to catch up with and overtake the advanced capitalist countries in the production of major products per capita, require an ever greater involvement in the national economy of more and more new natural resources of the North..." (Slavin, 1961: 4).

Even a cursory acquaintance with the ideology of Marxism-Leninism allows us to understand that urbanization of the Arctic had a special significance: for that system cities and towns are not just large localities, but the places of concentration of the proletariat. They were considered progressive as opposed to peasant regions, and even more so to the "backward suburbs". That is why cities were seen as the true "crown" of socialist transformations. In the spirit of this ideology, the Arctic space of national villages, such as, for example, Canadian or Alaskan ones, could not satisfy the tasks of large-scale socialist transformations. Only proletarian cities and towns in those years could signify the triumph of socialism, namely, the towns "shining with lights" (by the way, it is a parallel with the Leninist formula of communism through the electrification of the whole country) became the measure of the success for the development of the North. Obviously, this ideological foundation determined the "correct" version of the Soviet North, which shall be urban. So, the Far North saw towns growing.

The young Igarka perfectly illustrates the early policy of the Soviet government in relation to the development of the North, which implied the transformation of the "backward outskirts" into a new socialist reality.

Let us pay attention to the fact that in the process of creating the young cities and towns of the Far North, much attention was paid to their "full value", they should have been not just industrial centres, but also loci of civilization of the surrounding territory. We may turn to the first book about the town written in 1935, when it was only six years old: "The role of Igarka in the task of developing the Far North is also great because in places where culture, technology and its revolutionary influence were previously unknown, where the economy of tsarist Russia ended up with a primitive standard of living with a natural and semi-natural way of life, there appeared a town with growing population, the working class, electricity, schools, hospitals, cinema, clubs, etc." (Ostroumova et al., 1935: 7).

Now let us take another mental step, and there is an analogy: in the early USSR, during the development of the North, the Jack London effect was deliberately assumed, presupposing the transition from a raw-materials based, immature, unbalanced economy to a full-fledged, "normal" society of an ordinary, non-frontier town. By and large, in the end the development of the North should have destroyed the North as a concept. However, in the case of Igarka, the situation was exactly the opposite: after the initial take-off in the $1930 \mathrm{~s}$, record production and the seemingly economic prosperity of the 
1970s and 80s, there followed a crushing fall all the more strange that the economy of Igarka was based on the benefits of its economic and geographical location, which, unlike mineral deposits, it would seem, could not have been exhausted.

\section{Igarka as a frontier: a rethinking} of the already known.

\section{Geographical location as a "deposit"}

Most often, the frontier emerges following the unexpected "discovery" of a new type of resource, in connection with the discovery of the resource itself or the possibilities of its extraction or transportation. A well-known example of the former factor is the discovery of the prairies of the Great Plains for American colonists coupled with the invention of a steel plough capable of lifting a powerful layer of steppe turf (Billington et al., 1949: 693-694). The informational, technological, infrastructural, barriers are thus broken down.

The construction of Igarka triggered the mass export of the Yenisei timber, and Igarka was chosen as a unique place for the junction of river and sea navigation: rafts could travel there relatively safely (further downstream the Yenisei, with almost constant sea storm winds timber rafting could have been too difficult) and at the same time the depth was enough for ocean ships to enter the port: "The southernmost harbour available for deep-sea vessels on the Yenisei, the Igarka anabranch, is at the same time the northernmost point that allows rather safe rafting in the river anabranch", such was the evidence of 1928 (Cited by Gorchakov, 1995: 44).

Moreover, convenient anabranch allowed ships to shelter from storms (common in this area of the Yenisei basin), as well as to winter in relatively safe conditions (whereas port cranes in Dudinka still have to be lifted up to the hill every year, to be saved from ice drift, in Igarka there are no such problems due to the anabranch). Nonetheless, technological innovation was also important: there was found a cheap way of mass timber transportation along the Yenisei, at the same time not only technological barrier, but also psychological one were removed: the same already cited Gorchakov wrote how the very possibility of mass transportation of timber along the Yenisei was demonstrated. This is the timber self-transportation by rafts of Volga type instead of delivery by means of tugboats. And this was implemented to a great extent thanks to personal initiative of a native of the Volga region - B.V. Lavrov, who was appointed the chairman of Komsevmorput, Northern Sea Route Committee (Rostislav Gorchakov describes how Lavrov invited to the Yenisei rafters from Vyatka, and how in 1930 the head of forest management of Komsevmorput F.P. Tetenkin personally headed the lead raft through rapids) (Gorchakov, 1995: 53-54). There were also purely infrastructural changes: in 1934 the most complicated to be passed Osinovsky rapid on the Yenisei was blown up.

Igarka's location, which ideally suited the transshipping of floating timber, turned out to be played out when the self-rafting of timber finished. For other means of transportation, Igarka retains some advantages (first of all, convenient anabranch), but as Dudinka's experience shows, they are no longer meaningful. According to economists, the location of Igarka turned out to be a specific asset, i.e. an asset suitable mainly for one use, such as, for example, a rare metal deposit (suitable only for metal mining). Under current conditions, the delivery of timber from Lesosibirsk using modern mixed-type vessels (river-sea vessels) is more advantageous than through Igarka, which, in fact, is no longer needed as a port. Despite this, V.E. Golenkov's estimates show that even under modern conditions (as for 2007) timber export through Igarka can be profitable, but this is true only if a number of conditions are met, for instance, when timber is exported to northern European countries (Golenkov, 2007).

Therefore, Igarka's location can be considered as a kind of "deposit", which opens possibilities of obtaining economic benefits at a certain stage, but which then runs out of these possibilities. However, a new question comes up, why did Igarka continue to function in the 1960-80s, when there was a move to timber exports in unit loads instead of on rafts, when mixed-type vessels appeared? The exhaustion of the initial "deposit" did not lead to the closing of a town. Moreover, maximum indicators 
in timber exports were reached in the 1970s. And vice versa, why did not its potential, gained during the years of prosperity, save it from the collapse in the post-construction period, why did not this famous town get Jack London's effect without turning into a complex centre of the development of the lower Yenisei?

\section{Igarka in the 1970s:}

\section{the rise or the sunset?}

During an interview a lot of informants called 1970s and 1980s the best period for Igarka, its "golden age". Actually, record levels in town's key economic sectors were reached during this period. The maximum amount of timber, precisely $1,322.5$ cubic meters (a comparable, but lesser, export volume remained until 1990) was sent through Igarka in 1978.

Igarka was being radically transformed during these years; multi-storied buildings (5-9 storeys) were being built massively: the socalled first and second micro-districts were being built in the 1970s and mainly in the 1980s, respectively. "More than 32 thousand square meters of living space in new stone buildings were completed in the $10^{\text {th }}$ five-year period [1976-1980 - Author's note]. The "first-born" high-rise buildings are growing - nine-storey buildings" - this passage was written in the anniversary in 1979" (Novikov, Troshev, 1979). These micro-districts - new buildings, by the way, make essence of what remains of Igarka today (Fig. 1).
Finally, a colossal victory was won over remoteness: a direct flight to Moscow was launched in 1977 (Gorchakov, 1995: 176).

The town was seemingly booming. The continued development of the transshipment in Igarka despite the loss of the advantages of the town's position compared to the times of self-rafting is easy to explain by the wellknown phenomenon for economists as "path dependence " and increasing returns on the use of already inhabited place: it is more simple to continue, where the town has already built its infrastructure. However, one can deduce after the detailed study of Igarka's evolution that the depth of crises of the 1990s resulted from the previous period of Igarka's development, specifically in the 1970-80s.

Breakthrough and revolutionary decisions were made earlier, in the 1960s. So, record volumes of timber transshipment, many times more than pre-war level, were made possible by the introduction of a new transportation technology in the previous decade: not induvial logs were overloaded in Igarka but powerful unit loads, often straight from a barge to a timber truck, without being unloaded onto the river bank. A new Igarka's part, "New Town", appeared after a fire in 1962 (mostly consisting of two-storey buildings), a new general plan was developed (providing for the micro-districts, which were being built over the next two decades). The image of "White stone Igarka" was being spread (a construction of the first

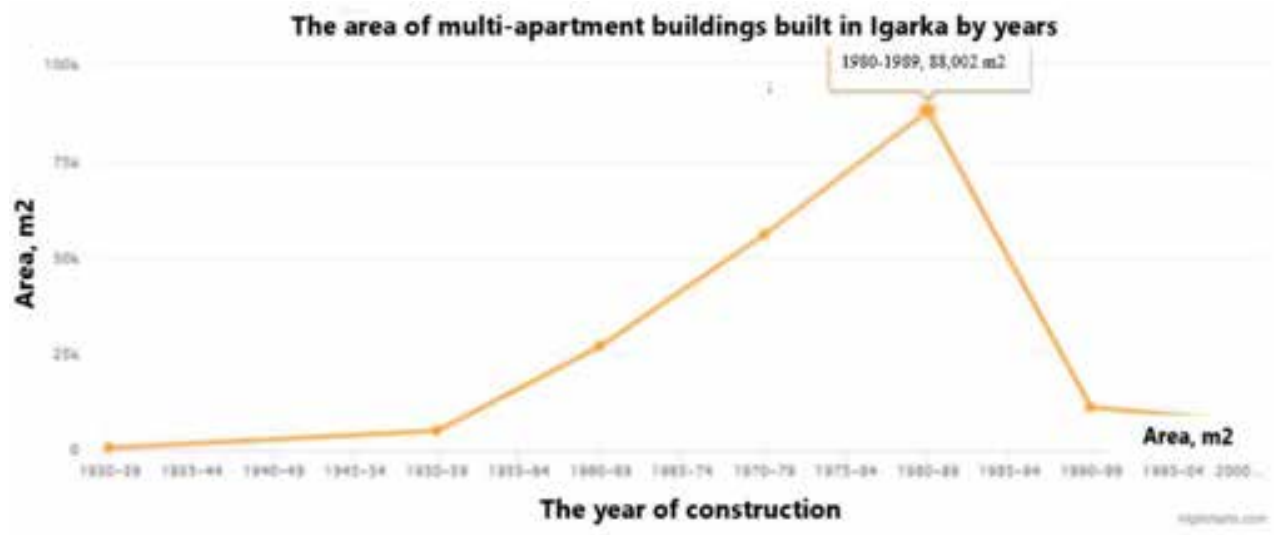

Fig. 1. The distribution of modern multi-apartment buildings in Igarka by construction period. Source: Dom.MinZhKH.RU. Available at: http://dom.mingkh.ru/krasnoyarskiy-kray/igarka/\#stats 
multi-storey micro-districts in the 1960s started with the construction of a light coloured (panel) buildings, yet, following five and nine-storey buildings were made of red brick); the image reflected the Igarka's transformation in the "real" town. The town television was launched in 1964; in 1963 there opened the unique underground part of the permafrost museum (in the mine, transferred from the research station). The first cruise ship entered Igarka in 1966: that is how the development of the tourism industry started.

In the 1970s, development was no longer qualitative but quantitative. Meanwhile, gross figures were often achieved at the expense of quality. For example, loading timber onto timber trucks requires special skills and experience, but because of the severe shortage of manpower, seasonal workers were massively involved in loading ${ }^{2}$. Here the witness is a famous writer V. Konetskii, who came to Igarka in 1975 as a captain of a timber carrier: he horrified at recalling about the admission of careless students to loading (Konetskii, 2007: 434):

"By nine o'clock in the morning, barges came under both sides and dockers appeared, verdant youth, students from Siberian universities. Basically, the future chemists, specialists in pulp and paper manufacturing... The profession of a docker is complicated and difficult. It is mastered over the years, the docker must have special training and a plenty of experience. Working with boards is dangerous and requires compliance with both the rules of safety and rules for laying the boards in the holds. College kids do not understand and do not know anything about all this. It is terrifying to see girls in the role of tallymen running on a bulwark, flirting with everybody, or standing under a bundle of boards that is lowered into

\footnotetext{
2 It stands to reason that seasonal workers have been involved in port operations for almost the entire history of the port, and the dynamics cannot be traced; it is curious that, however, in the first half of the 1930s the authorities insisted on the reduction in the number of seasonal workers: "Almost all of these points of production united several industries... in such a way that within each economic hub, these industries would ensure full employment and full use of the workforce, giving free reign only to certain industries to bring in seasonal workers for loading and fishing. (Slavin, 1961: 116; see also: Gorchakov, 1995).
}

the hold, with their heads pulled up and their mouth opened, into the mouths every second a five-meter-long piece of timber can be pierce. One of the girls on this navigation has already been slammed. It's called as such: "Lack of workforce."

Apparently, similar substitution of quality by gross indicators occurred in other areas as well; in particular, the massively built apartments in the $1970 \mathrm{~s}$, on average, were more cramped than apartments in older houses (Fig. 2).

The general policy of domination of departmental interests in the raw-materials based areas, which was typical for the era, was complemented by the need to build everything for the sake of industry. E.G. Smirnova, the chief specialist on architecture and building control, told how in the 1980s it was necessary to commission building cultural institutions (in particular, school of arts) as apartments or industrial premises: according to the norms, Igarka was not entitled to "any more culture".

This statement contradicts the official rhetoric of those years, which looks quite frontier, almost in the spirit of Turner: the spirit of the pioneers allows you to go to new victories. Let us turn to reading the jubilee edition:

"Much has been done in Igarka in fifty years. The town was built in permafrost. The first mill in the Arctic Circle. The first sovkhoz. The first airport. Everything for the first time. And this is the main object of pride. But people cannot be satisfied with what has been achieved. Are there houses with gas-fired furnaces? Good! But we have to make the town fully gasified. And even better, electrified: a power transmission substation is being built for that purpose today. Upon being included in the united Taimyr "energy ring", Igarka will get a huge flow of energy.

Once, on its fifth anniversary, the dwellers of Igarka were proud: "100 passengers were carried". Now aviators dream: '100 passengers per hour'. <...>

And it does not seem a fantastic dream to navigate the Northern Sea Route all year round" (Novikov, Troshev, 1979).

But if you think about it thoroughly, it is a gradual replacement of fundamental inno- 


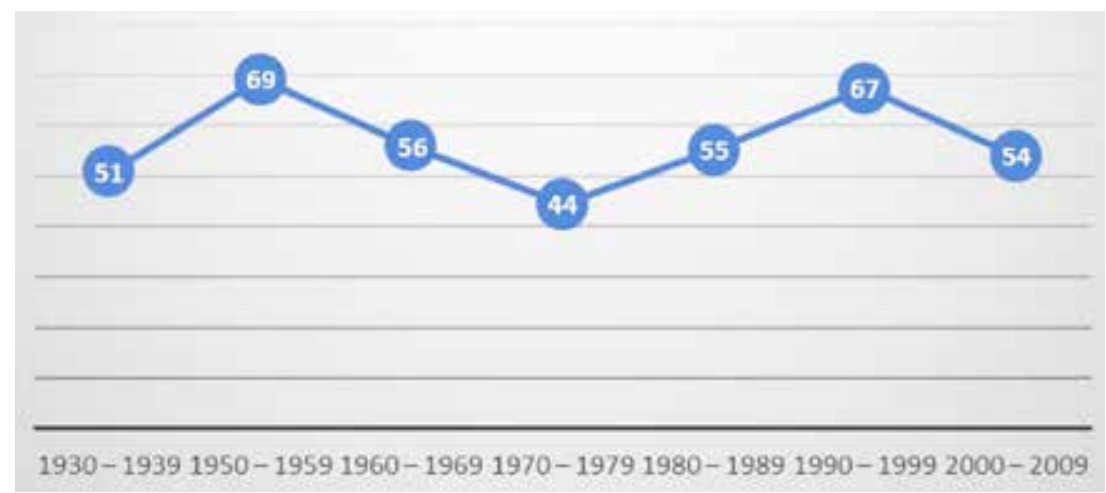

Fig. 2. Dynamics of average living space in Igarka per one apartment - by periods of construction (as regards the houses that were there in 2019).

Source: Dom.MINZhKKH.RU. Available at: http://dom.mingkh.ru/krasnoyarskiy-kray/igarka/\#stats

vations with quantitative growth. The history frontier itself ends (or its first phase, depending on the date) and the era of mass production begins.

The transition to the epoch of mass production is a qualitative boundary: the innovative potential of the frontier line is dwindling, and the institutional and production systems are "withering". The main signs of reducing everything to the needs of production are loss of creativity, diversity of production and cultural life, absence of radical innovations; and all these events happened when production indicators were at their peak. As a matter of fact, in its "golden age" Igarka became even more "mono-profile", narrowly specialized town, it lost its originality and diversity of economy and urban environment.

Let us try to assess indirectly the level of diversity and innovative potential of the local socio-economic system of the "golden age" compared to the $1930 \mathrm{~s}$, as well as to the current situation. As for the first years of Igarka's existence, there is a document, remarkable in its detailedness: this brochure was prepared in 1935 to represent the town during the visit of the Town Council delegation to M.I. Kalinin. The document contains specific facts, and even with an allowance for its evidently "demonstrative" character, it correlates well with other sources and can be considered an excellent "encyclopedia" of culture and economy of Igarka in the first years of its existence. For com- parison, let us take the $1960 \mathrm{~s}$ - the decade of breakthrough to the revolutionary new technology of timber loading; the 1970s - the decade of record indicators of timber export and the modern period after the termination of timber export (unless otherwise stated, the main data are given according to the book by R. Gorchakov) (Tabl. 1).

Even passing reference of genuinely experimental, innovative technical decisions, research infrastructure objects, scientific, educational and culture institutions, which had already been built by 1935 and were enlisted in considered brochure, is really striking. Moreover, majority of them served not only Igarka, but also surrounding territories:

"Now Igarka became the only construction site serving the whole Far North: Dudin$\mathrm{ka}$, Norilsk, Ust-Port and the other places of Taimyr District are supplied with timber from Igarka's lumber mill. Standard north houses (winter huts, etc.) are fully completed in Igarka and transferred to their destination in disconnected parts. Igarka's experimental agricultural works are exclusively important for the whole Far North. Igarka's experiments proved that problems of growing vegetables and other agricultural plants can be successfully solved in Siberian Arctic Circle conditions. This will greatly remove the agricultural edge. Igarka's experiments are already integrated in other Northern sites, where Igarka's conclusions stood up to reality again. In 1934 Dudinka, 

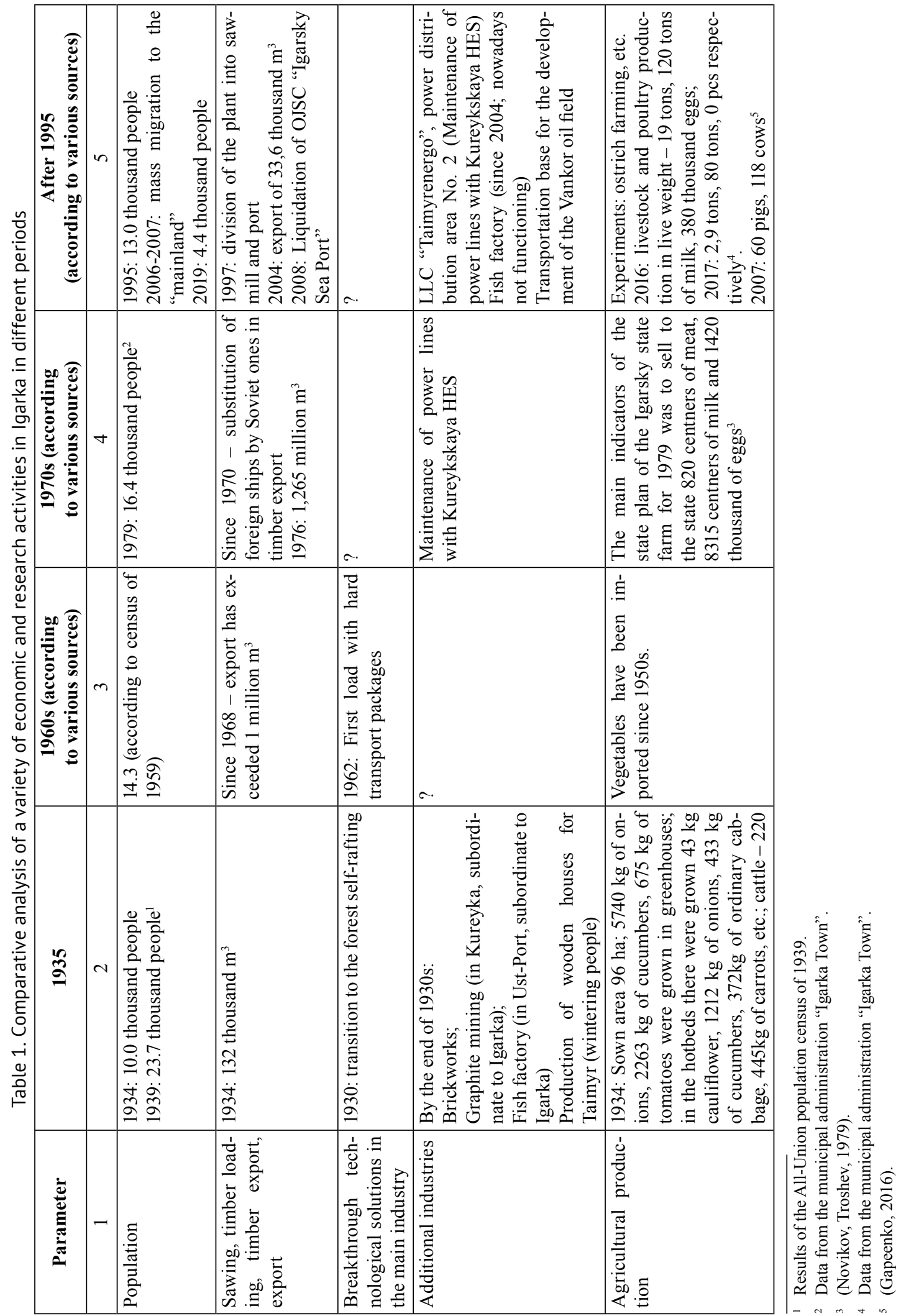


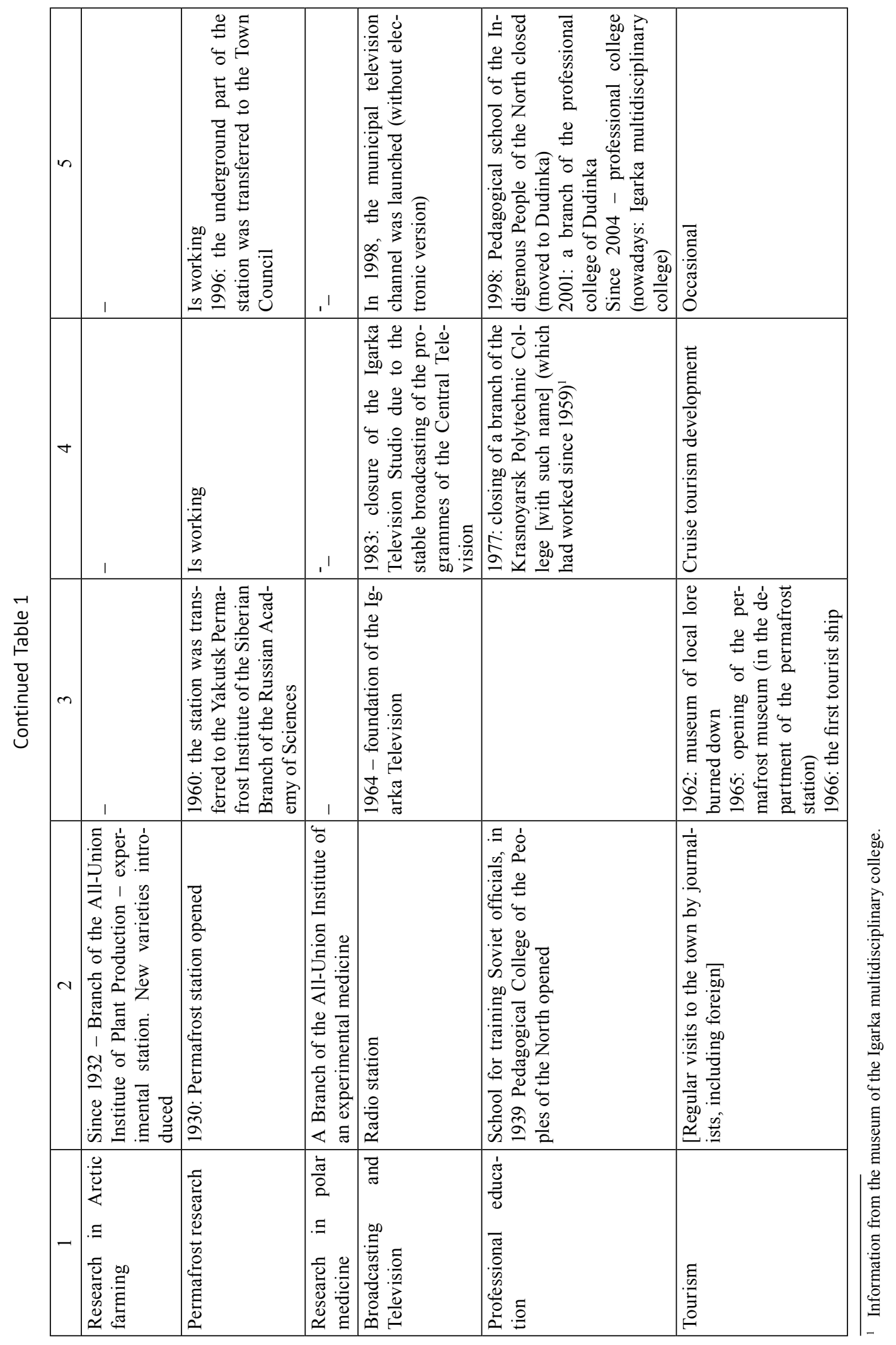


Ust-Port and other towns planted vegetables on their own premises with Igarka's seeds. Igarka's Soviet Party School <for training officials $>$ prepares Soviet and Party staff for all Far North. ...Igarka branch office of "Experimental Medicine Institute" has a huge importance... technical importance of Igarka permafrost station ought to be clear. Igarka's cultural institutions - hospitals, schools, clubs, etc. have not only local, town importance, but partly they serve other far North districts population. In this connection one should acknowledge a big cultural role of radio station, which is one of the most powerful in Krasnoyarsk Krai...Being the big centre-consumer, Igarka always has huge stores of goods, which help to cover needs of neighbouring districts in rigorous times, including Taimyr district. For example, in winter of 1934 Igarka transferred goods of 1,500 thousand rubles cost to Taimyr district" (Ostroumova et al., 1935: 7-9).

Particularly it was a potential try on diversification, on Jack London's effect, and it was expected to be widely spread by building "business house", a kind of club for engineering technical staff. This club also can be used for technical studies and further training of Igarka workers..." (Ostroumova et al., 1935: 41).

Igarka in 1970 was a field-specific centre of timber sawing and transshipping; a serving centre for navigation equipment and north aviation, a base for several geological expeditions. But "after boom" Igarka lost any facilities which could have furnished innovations, strengthen economic development base: in 1977 Igarka branch office of timber college moved to Krasnoyarsk. Growing of vegetables, which were bred in Igarka, stopped, except personal subsidiary plots; local television closed; wooden housebuilding perished, in other words, the perspective of future specialization dissolved into thin air.

It is interesting that population against active production successes did not grow, but always fluctuated. In the anniversary year of 1979 , it amounted to 16.5 thousand of people, it is lesser than in 1955 (20,000 people).

Crossroads time. In 2005 timber transshipment in Igarka ceased forever. For several previous years the town had suffered the hard- est times: the plant employees had been given food coupons (on the black market they could be exchanged for money at an unfavourable rate). In the most advantageous position were those whose job was connected with the extraction of fish, the respondents report that only those engaged in fishing, for example, were able to send their children to study in Krasnoyarsk.

There were several components of the Igarka's collapse. The fundamental one was the exhaustion of the potential economic benefits of timber transshipment from river to sea vessels, though surprisingly, it did not play the key role. More important was the desire of the "upper mills", which had traditionally supplied timber to Igarka, to work directly with the customers in the troubled years; the timber was shipped for export by rail and further through Novorossiysk. The choice of the southern route was greatly facilitated by the introduction of the socalled "ice dues": in a nutshell, for the sake of maintaining the viability of the icebreaker fleet (officially for the sake of preserving the entire navigation facilities of the Northern Sea Route) there were introduced tonnage dues for the passage along the Northern Sea Route, moreover, they were collected even in the summer time, when no icebreakers are used ${ }^{3}$.

This aspect is worth dwelling in more detail. The widespread use of the nuclear icebreaker fleet (the first atomic icebreaker "Lenin" was put into operation in 1959, however, the situation on the Northern Sea Route changed radically in the 1970s) helped extend-

\footnotetext{
3 Item 3.7.6 of "Price list N 11-01. Tariffs for the carriage of goods by sea (coastal navigation)" (approved by Decree of the State Committee on Prices of the USSR of 27.03.1989 N 274) asserts as follows: "Dues for icebreakers shall be levied once per ton (container) of the cargo being transported, arriving or departing from (to) ports of the Northern Sea Route, or being transported through the NSR as transit by coastal navigation and foreign voyages year-round, also year-round fee shall be levied for passing along the NSR of vessels not belonging to the Ministry of Maritime Fleet of the USSR". The dues introduction is motivated by the fact that "ice tonnage dues are charged by the NSR company from the consignor not in connection with the transportation of exported cargoes, but for the implementation of a set of measures aimed at maintaining navigation, that is, for the provision of services to ensure the safety of navigation during the passage of Russian vessels, including those owned by the company, along the Northern Sea Route" (citation from the Decree of Federal Arbitration Court of North-Western District of 26.05.2005 N A42-1315/04-22).
} 
ing the navigation period, increasing the capacity of the NSR (the queue of ships to be loaded in Igarka was in every description of it in 1960-1980s). However, the victory over nature was very expensive here. The widespread use of the nuclear icebreaker fleet, in fact, brought the NSR into a new state. The ice road became almost all-weather, but also very expensive in general. For several cargoes extending the navigation period paradoxically made the course economically unprofitable, since it became more expensive (certainly, it would have been possible to introduce some kind of electoral tariffs, but this was not done). In fact, "ice dues" actually prevented the NRS from transporting goods at a relatively low cost (including lumber); there was only transportation of such more expensive cargoes as oil, nickel concentrate; in the last years liquefied natural gas has joined the league. The general crisis of the NSR led to the decline and technical degradation of all the ports of the Arctic Ocean, not associated with high-cost cargoes, including the "timber" Igarka. In fact, it was the second factor (along with the rejection of timber self-rafting) that eliminated the uniqueness of Igarka's location.

But was there any other possible plot apart from economic and social collapse? In the theory, we can imagine the development on the basis of Igarka of a scientific research and cultural centre similar to Fairbanks, which, after the end of the gold rush, would become a university centre in 1917. In the Russian version, there is a possible analogue - the Apatity town with its Kolsky Science Centre of the Russian Academy of Sciences. Both equivalents are factitious: they are in much better transport situation. However, as shown in the previous section, Igarka lost a part of its scientific, creative capital before the crisis. Then the bases of geological exploration expeditions stopped working - this would happen practically throughout the country, geology declined and researchers "pulled together" into large centres.

However, at the basic level probably any town can envy Igarka's creativity under such difficult conditions. Ostriches were brought here, the authorities promised the development of an international yacht club, an underwater power station; the remarkable project "Tras- polar Igarka: the archive revives the town" in 2005 was among the winners of the $2^{\text {nd }}$ contest "Changing Museum in a Changing World" (Zapoliarnaia Igarka...). Apparently, there was not enough critical mass of capital (human, financial, capital of trust in the territory), there was a sufficient number of creative projects, but there was a lack of industries already formed during the boom years that could have become the main new economy. Perhaps the only one of these industries is tourism. However, the damage to the tourism sector was caused by the loss of the originality of the urban landscape, and again one has to admit that the foundation was laid already in the 1970s, when typical houses were built in Igarka, although the completely historical landscape of the town was destroyed back in 2010, during the recultivation programme, when, in order to save budget for the support of extensive communal networks, the entire remaining population of the town was resettled in two microdistricts, and the rest of the territory, in fact, was burned ${ }^{4}$.

Undoubtedly, the negative factor was the fact that Norilsk industrial region laid hands on the majority of scientific and educational functions of Igarka (research in polar medicine, agriculture of the Far North and especially geocryology).

It is needless to say that the status of a district centre would have helped Igarka a lot, but the Soviet system of granting northern industrial towns the status of a town of regional/ Krai subordination undermined this possibility, and therefore Igarka obviously "did not accumulate" enough potential for becoming an administrative and organizational centre of the surrounding area - although in fact it has always been such centre, even today (for example, Svetlogorsk Hospital "is subordinated" to Igarka). ${ }^{5}$ It is interesting that in 1990 among the attempts to find a new economic base for the town development the Igarka Town Council ratified the Declaration on the Establishment of the North-Yenisei Oblast (Norilsk, Dudinka, Khatanga, Dixon, Ust-Yeniseisk, Talnakh, Kayerkan, Igarka) with the possibility of creat-

\footnotetext{
4 Based on interviews in Igarka.

5 Interview with the chief physician in Igarka's hospital, 2018.
} 
ing a free economic zone in Igarka (Gorchakov, 1995)

Everything that was described above said makes one reevaluate the golden age of Igarka. The "fat" 1970-80s did not lay down anything that would have helped Igarka to survive the crisis of the 1990s and the subsequent difficult external economic conditions, on the contrary, Igarka lost potential "institutions of knowledge", research and educational institutions exactly in its golden age. The "golden age" of mass production and exacerbation of narrow specialization (set in the pre-war years after repressions in the Northern Sea Route system, and repeatedly reinforced by pursuit of gross indices in the last decades of Soviet power) turned out to weaken its urban system which could hardly face the economic difficulties of the 1990s. By no means justifying the irresponsible decisions of the 1990s (in particular, the closure of the town-forming enterprise without evacuating the town population), the numerous economic abuses and even crimes at the time, the general policy of the leadership of the country on "leaving the North", largely inspired by the World Bank (cf., e.g., Mel'nikova, 2005), I can conclude: possibilities to build alternative, scientific-research, tourist, educational economic specialization (which would have flourished in the new stage of the town development with the arrival of Vancorneft JSC) were not promoted, instead they were, in many ways, squandered during the period of the largest economic indicators, in the 1970s-1980s, during the period of construction of the "model" town called Igarka.

\section{Conclusions}

The example of Igarka is a fascinating encyclopedia of lessons in the development of resource territories. The first lesson, of course, is to link the advantages of a location to a specific technology that potentially threatens the well-being of any transport hub. Loss of advantages connected with location, you can say, is the typical fate of many and many transport hubs that have appeared on the main tracks from a deep antiquity, and disappeared from the map together with the paths, Igarka is more interesting by another thing. The second lesson of Igarka is, on the contrary, the inertia of the situation in the Arctic. Practically any "bit" of development in conditions of complete absence of roads for hundreds of kilometers creates to even little developed areas colossal advantages of increasing output. Kosmachev at his time wrote about the role of scattered taiga wooden cabins as the first "bases" for the development of resource areas - the presence of at least a cabin made it easier to enter the virgin territory (Kosmachev, 1974). All the more reason, the town turns out to be a more effective point for a new wave of development than working from scratch, despite the weakening influence of the initial advantages of geographical position.

In Igarka, during the transition to the export mode of unit loads there was increasing return from the previously created infrastructure (although the assessment of the port's performance in the 1970s raises questions and requires a separate study), and even more so in recent decades, when Igarka turned out to be "useful" for the development of a new Vankor oil field. Development of Vankor, by the way, teaches another lesson, which is bitter again: in modern conditions, the cycle of demand for the town in the development of the field is limited, in fact, by several years, while the development is underway, but this topic is beyond the scope of this article.

The fourth and most important lesson of Igarka is the sharp contradiction between gross production indices and the diversity of the urban environment, virtually between the momentary economic efficiency of production and the viability of the town oriented to production. Having reached record levels in the 1970s, Igarka lost the diversity of the town economy, and after the collapse of the town-forming enterprise it become frail during the crisis.

As it is known from Jacobs' books, the contradiction between short-term production efficiency and long-term viability, brilliantly illustrated by the comparison of the highly specialized Manchester and the multi-sector Birmingham, takes on a special meaning in the Arctic. Typically, this contradiction is seen as a dilemma "production centre - the base of development", or "the town at the deposit / the base for the development of the entire district". 
And this can also be seen by the example of Igarka.

The town's position among other economic centres of the North of the Krasnoyarsk Krai has played a big role. Being a pioneer of development in the region, in the early years Igarka played the role of a centre for the development of new settlements; it was used for air reconnaissance, radio communications, it supplied construction materials, products and experience. If Igarka had established itself as an economic centre of the lower reaches of the Yenisei, especially if it had become an administrative centre, it would obviously have had a completely different fate. This is proved by comparison with Naryan-Mar, which has lost the timber export industry (the timber factory in Naryan-Mar after a number of conversions was declared bankrupt in 2010, Igarka's timber processing plant, also after a number of conversions, went bankrupt in 2008 , as well as Igarka's sea port). But it stayed the capital of Nenets Autonomous Okrug. However, due to the greater economic importance of Norilsk, the younger "brother" of Igarka, most of the functions of the "central place" associated with the maintenance of the surrounding area (scientific, educational, cultural, infrastructure management, communications) passed to this town. Igarka turned from a centre of the territory development into a highly specialized industrial centre, and that is what apparently deprived it of the possibility to survive in the general crisis of the Far North.

This is where the roots of the impossibility of the Jack London's effect are: having focused on implementing narrow production tasks, having "parted with" specialized education and agriculture, television broadcasting and scientific research (except for permafrost studies), Igarka lost the very "service" industries, which followed the main raw materials-based ones, which at the end of the resource boom could have become the basis for the further existence of the town. In the name of viability.

Upon reestimating the situation of Igarka, not just as a case of the collapse of the town-forming enterprise, but as a case of loss of the role in becoming the centre for the territory development, one can find many analogues in Russia. Such cases occurred, for example, in the interior parts of Kolyma, where in the early 1930s it was even planned to relocate the administrative centre of the new district, and which are almost depopulated at present. Such are certain settlements and towns in the region of rich oil and gas fields of Western Siberia, which are now in dead ends of transport routes, on the economic and social periphery due to the rise of Nizhnevartovsk and even more - Surgut; some bright examples of such "dead-end" settlements are the town Raduzhny, and the settlement of Novoagansk.

This teaches a lesson for all existing resource centres of the Arctic, and Norilsk first of all. Norilsk loses the opportunity to reach Jack London effect in the long run by not fulfilling the functions of the development of the surrounding territory; such social functions as education, medical services and alike were transferred to Dudinka; tourism, the media, scientific research, etc., are focused on serving the needs of the town itself, and, apart from tourism, experience a serious crisis. Having lost the status of the administrative centre of a subject of the Russian Federation, Dudinka suffers the losses of these opportunities of growth and development, too. Undoubtedly, it does not concern the "eternal" preservation of cities in the same size, this refers to preserving the basic functions of scientific, educational, service industries of the vast surrounding area, preserving viable centres despite possible radical changes both in the town-forming industry and in the number of population. Meanwhile, as Igarka's second lesson shows, the future development of the Arctic may suddenly call for any once developed area, the preservation of the developed islands in the middle of the "white silence"; so, the preservation of potential bases even in seemingly "worked out" areas is an important relay baton to pass to future generations. 


\section{References}

Analiticheskaia spravka ob osnovnylh sotsial'no-ekonomicheskikh pokazateliakh munitsipal'nogo obrazovaniia gorod Igarka 2012-2017 gg. (Dannye administratsii MO "Gorod Igarka") [Analytical report on the main socio-economic indicators of Igarka town in 2012-2017. (Data from the municipal administration "Igarka Town")].

Assche Van, K., Deacon, L., Gruzmacher, M. et al. (2016). Boom \& Bust: A Guide to managing ups and downs in communities. Edmonton, Alberta, University of Alberta, 234 p, available at: https://issuu. com/uaextension/docs/boom_and_bust_a_guide

Billington, R.A., Hedges, J.B. (1949). Westward Expansion: A History of the American Frontier. New York, The McMillan Company, 893 p.

Dom.MinGKH.RU: Obshchestvennyi proekt. Informatsiia o domakh v Rossii. Igarka [Public project. Information about housing in Russia. Igarka], available at: http://dom.mingkh.ru/krasnoyarskiy-kray/igarka/

Gapeenko, V. (2016). Zona riskovannogo zemledeliia [Risky farming zone]. Personal blog, available at: https://gapeenko.net/chronograph/6239-zona-riskovannogo-zemledeliya.html_(date of access: 02 April 2016).

Goldsmith, O.S., Berman, M., Huskey, L. (1987). An interactive multiregional model of a frontier economy: Anchorage and the State of Alaska. In Regional Science Perspectives, 17 (1), 55-76.

Golenkov, V.E. (2007). Sovershenstvovanie tekhniko-ekonomicheskoi otsenki razvitiia regional'nogo vodnogo transporta na primere transportnoi sistemy "Enisei - Severnyi Morskoi Put"” [Improving the technical and economic assessment of the development of regional water transport on the example of the transport system "Yenisei - Northern Sea Route"]. Abstract of Thesis of Candidate of Economic Sciences. Saint-Petersburg.

Gorchakov, R. (1995). Udivitel'naia Igarka [Amazing Igarka]. Krasnoyarsk, Publishing House "Medved", "Inkombuk", $210 \mathrm{p}$.

Huskey, L. (1987). Import Substitution. The Hidden Dynamic in the Growth of Frontier Regions. In Developing America's North Frontier, 43-55, ed. by T. Lane. Anchorage.

Huskey, L. (2017). Alaska's Economy: The First World War, Frontier Fragility, and Jack London. In Northern Review, 44, 327-346.

Itogi Vsesoiuznoi perepisi naseleniia 1939 g. [Results of the All-Union population census of 1939], available at: http://www.demoscope.ru/weekly/ssp/rus_pop_39_3.php

Konetskii, V. (2007). Vcherashnie zaboty [Yesterday's worries]. Moscow, Publishing House "AST", “Text", 590 p.

Kosmachev, K.P. (1974). Pionernoe osvoenie taiga: ekonomiko-geograficheskie problem [Pioneering the development of taiga: economic and geographical problems], ed. by academician V.B. Sochava. USSR Academy of Sciences, Sib. Department, Institute of Geography of Siberia and the Far East, Novosibirsk, "Nauka". Siberian branch,144 p.

Mel'nikova, L.V. (2005). Glava 1: Osvoenie Sibiri v zerkale liberal'noi ekonomicheskoi nauki [Chapter 1: Development of Siberia in the mirror of liberal economics]. In Problemnye region resursnogo tipa: Aziatskaia chast' Rossii [Problematic regions of the resource type: Asian part of Russia], 34-47, ed. by V.A. Lamin, V.Iu. Malov. Novosibirsk, Publishing House of the SB RAS.

Nevenkin, K.G., Lapin, G.P. (1975). Lesnoi eksport s Eniseia: Posobie dlia rabotnikov lesoeksportnykh predpriaitii Sibiri [Forest Export from the Yenisei region: Manual for employees of Siberian timber export enterprises], ed. by N.A. Nikonenko. Krasnoyarsk, Krasnoyarsk Publishing House, 280 p.

Novikov, V.F., Troshev, Zh.P. (1979). Igarka - goroda Krasnoiarskogo kraia. K 50-letiiu goroda Igarka [Igarka - cities of the Krasnoyarsk Krai. On the $50^{\text {th }}$ anniversary of Igarka town]. In Seriia "Goroda Krasnoiarskogo kraia" ["Krasnoyarsk Krai Cities" Series]. Krasnoyarsk, Krasnoyarsk Publishing House, 120 p., 11 pictures, available at: https://31marta.ru/igarka-goroda-krasnojarskogo-kraja-novikov-v-f-troshev-zhp-16-06-1979-god-kniga-polnyj-tekst/) 
Ostroumova, V.P., Brilinskii, I.V., Chepurnov (eds.) (1935). Igarka. Igarka Municipal Council Publishing, Krasnoyarsk, Publishing House "Krasnoyarsky Rabochy", 45 p.

Preiskurant N 11-01. Tarify na perevozki gruzov morskim transportom v kabotazhnom plavaniii (utv. Postanovlenien Goskomtsen SSSR ot 27.03.N 274 [Price list N 11-01. Tariffs for the carriage of goods by sea in coastal navigation (approved by the Decree of the USSR State Committee of 27 March 1989)].

Slavin, S.V. (1961). Promyshlennoe i transportnoe osvoenie Severa SSSR [Industrial and transport development of the North of the USSR]. Moscow, Publishing House of Economic Literature, $302 \mathrm{p}$.

Turner, F.J. (1893). The Significance of the Frontier in American History, In Annual Report of the American Historical Association for 1893, 199-227. Washington, D.C.

Turner, F.J. (2009). Frontir v Amerikanskoi istorii [Frontier in American history]. Moscow, Publishing House "Ves' Mir", 304 p.

XVII s'ezd Vsesoiuznoi kommunisticheskoi partii (b). 26 ianvaria - 10 fevralia 1934 g. Stenograficheskii otchet [17 ${ }^{\text {th }}$ Congress of the All-Union Communist Party (b). January 26-February 10, 1934. Verbatim report] (1934). Moscow, "Partizdat", 720 p.

XVIII s'ezd Vsesoiuznoi kommunisticheskoi partii (b). 10 - 21 marta 1939 g. Stenograficheskii otchet [18 ${ }^{\text {th }}$ Congress of the All-Union Communist Party (b). March 10-21, 1939. Verbatim report] (1939). OGIZ, State Publishing House of Political Literature, $740 \mathrm{p}$.

Zapoliarnaia Igarka: arkhiv vozrozhdaet gorod [Transpolar Igarka: the archive revives the town]. In Novosti muzeev [Museum news], available at: http://museum.ru/N23027 


\title{
Игарка как фронтир: уроки «пионера» Севморпути
}

\section{Н.Ю. Замятина}

Московский государственный университет имени М.В. Ломоносова

Российская Федераџия, Москва

Лаборатория исторической географии и регионалистики

Тюменского государственного университета

Российская Федеращия, Тюмень

\begin{abstract}
Аннотация. В статье рассматривается траектория развития Игарки, пионерного экспортного порта Севморпути, с точки зрения анализа возможностей сохранения города после краха градообразующего предприятия. Основной концептуальной рамкой анализа служит гипотеза «Джека Лондона» аляскинского экономиста Ли Хаски о возможности накопления фронтирными городами потенциала для дальнейшего развития в послебумовый период. Причиной современного экономического и социального кризиса Игарки видится не только изменение условий лесоэкспорта и судоходства по Северному морскому пути в 1990-е годы, но и сужение экономических функций города, а также уменьшение разнообразия городской среды в целом, парадоксально сопутствовавшее рекордным производственным показателям в последние советские десятилетия.
\end{abstract}

Ключевые слова: освоение, Северный морской путь, экспорт, транспорт, фронтир, циклическое экономическое развитие, «взлеты и падения», зависимость от пути, «эффект Джека Лондона».

Работа выполнена в рамках государственного задания Минобрнауки РФ № 33.2257.2017/ПЧ на тему «Российские гавани Трансарктической магистрали: Пространства и общества арктического побережья России накануне новой эпохи развития Северного морского пути».

Научная специальность: 22.00.00 - социологические науки. 